\title{
ANALISIS KINERJA KEUANGAN DAN PEMBANGUNAN DAERAH TERHADAP PERTUMBUHAN GERBANGKERTASUSILA \\ EKONOMI DI
}

\section{Wahyu Himatul Aliya, Aris Soelistyo}

Program Studi Ekonomi Pembangunan, Fkaultas Eknomi dan Bisnis, Universitas Muhammadiyah Malang, Jl.Raya Tlogomas No.246 Malang, Indonesia

* Corresponding author: arissoelistyo65@gmail.com

\begin{tabular}{lll}
\hline Artikel Info & Abstract \\
Article history: & & This study aims to determine how the effect of the Locally \\
Received 25 November 2019 & & Generated Revenue (PAD), balance fund, government capital \\
Revised 5 December 2019 & & expenditure, Human Development Index (HDI), and labor \\
Accepted 10 January 2020 & force total (AK) on economic growth. This study used \\
Available online 15 February & secondary data from 2008 until 2017. Analysis techniques is \\
2020 & quantitative, which use Panel Regression Method. Analysis \\
& results show that the estimation model analysis selected is \\
Keyword: Economic Growth, & Fixed Effect (FE). The results show that the PAD variable \\
Regional Government Budget, & has a significant positive effect on economic growth. The \\
Region Development & others variable while balance funds, government capital \\
Performance & expenditure, AK and HDI has a negative significant effects \\
& on economic growth in Gerbangkertasusila
\end{tabular}

JEL Classification

E01, H61

\section{PENDAHULUAN}

Sejak diterapkannya UU mengenai Otonomi Daerah pada tahun 2001, Anggaran Pendapatan dan Belanja Daerah (APBD) menjadi salah satu hal yang penting dalam rangka pelaksanaan desentralisasi di bidang keuangan, atau yang sering disebut dengan desentralisasi fiskal. Desentralisasi fiskal sendiri merupakan suatu kebijakan ekonomi yang digunakan pemerintah untuk mengelola/mengarahkan perekonomian ke kondisi yang lebih baik atau diinginkan dengan cara mengubah-ubah penerimaan dan pengeluaran pemerintah (Rahardja dan Manurung, 2008).

Pertumbuhan ekonomi menjadi suatu indikator penting dalam analisis terhadap pembangunan ekonomi, sehingga sampai saat ini masih digunakan sebagai indikator kemajuan perekonomian secara agregat (Nuraini, 2017). Tujuan utama pembangunan ekonomi adalah untuk mencapai kesejahteraan rakyatnya yang dapat tercermin dari tingginya tingkat pertumbuhan ekonomi (Nuraini, 2010). Kinerja pembangunan daerah merupakan cerminan dari pertumbuhan ekonomi yang terjadi di wilayah Kabupaten/Kota Gerbangkertasusila. Penilaian kinerja dapat diukur dari tingkat keserasian antara perencanaan dengan tujuan yang ingin dicapai.

Perencanaan dalam analisis terhadap APBD ini digambarkan sebagai besaran anggaran yang diberikan oleh pemerintah sebelum APBD dilaksanakan atau saat APBD disahkan. Sedangkan tujuan yang ingin dicapai adalah pertumbuhan ekonomi yang terjadi setelah APBD tersebut dilaksanakan (direalisasikan). Keserasian antara perencanaan dalam anggaran dengan hasil yang ingin dicapai tersebut merupakan suatu gambaran atau cerminan dari kinerja keuangan daerah, yang dalam penelitian ini diukur 
melalui APBD. Selanjutnya dari sisi kinerja pembangunan daerah, perencanaan digambarkan sebagai peningkatan kesejahteraan rakyat, dan tujuan yang ingin dicapai adalah pertumbuhan ekonomi yang terjadi akibat peningkatan kesejahteraan rakyat tersebut. Pertumbuhan ekonomi dalam penelitian ini diukur melalui Produk Domestik Regional Bruto (PDRB) Atas Dasar Harga Konstan (ADHK). Pasomba (2015), menjelaskan bahwa nilai tambah bruto mencakup komponen-komponen faktor pendapatan (upah, gaji, bunga, sewa tanah, dan keuntungan), penyusutan dan pajak tidak langsung neto.

Gerbangkertasusila adalah salah satu wilayah otonomi di Provinsi Jawa Timur yang sudah menerapkan kebijakan desentralisasi fiskal. Dikutip dari laman web Provinsi Jawa Timur (Jatim Prov), Gerbangkertasusila, akronim dari Kabupaten Gresik, Kabupaten Bangkalan, Kabupaten dan Kota Mojokerto, Kota Surabaya, Kabupaten Sidoarjo, dan Kabupaten Lamongan, merupakan salah satu wilayah yang masuk dalam bagian cluster metropolitan di Jawa Timur yang ditetapkan sebagai Pusat Kegiatan Nasional (PKN) dengan fungsi pelayanan dalam lingkup nasional atau beberapa provinsi. Cluster sendiri merupakan salah satu hal yang menjadi dasar penerapan kebijakan pengembangan wilayah guna meningkatkan pemerataan pertumbuhan ekonomi, infrastruktur, sosial dan budaya di seluruh wilayah Jawa Timur. Hal tersebut menjadi fokus pembangunan Jawa Timur tahun 2014-2019, dengan mengacu Perda Provinsi Jawa Timur No.5/2012 tentang Rencana Tata Ruang dan Tata Wilayah (RTRW) Provinsi Jawa Timur tahun 2011-2031, dan Perda Provinsi Jawa Timur No.3/2014 tentang Rencana Pembangunan Jangka Menengah Daerah (RPJMD) tahun 2014-2019.

Wilayah Gerbangkertasusila yang berpusat di Surabaya, merupakan wilayah metropolitan terbesar kedua di Indonesia setelah Jabodetabek yang pusatnya di Jakarta. Gerbangkertasusila yang mempunyai penduduk terbanyak kedua setelah Jabodetabek, juga merupakan pusat perekonomian di Provinsi Jawa Timur. Sebagian besar dari kabupaten/kotanya memiliki tingkat pertumbuhan ekonomi yang relatif tinggi dengan rata-rata berada di atas angka 5\% di setiap tahunnya, kecuali Kabupaten Bangkalan yang ratarata masih berada di bawah 1\%. Hal ini diketahui dari laju Produk Domestik Regional Bruto (PDRB) Atas Dasar Harga Konstan (ADHK) 2010 wilayah Gerbangkertasusila tahun 2013-2016 seperti yang tersaji dalam tabel di bawah.

Tabel 1. Laju Pertumbuhan Produk Domestik Regional Bruto Atas Dasar Harga Konstan 2010 Gerbangkertasusila tahun 2013-2016.

\begin{tabular}{lcccc}
\hline Kabupaten/ Kota & \multicolumn{4}{c}{ Tahun } \\
& $\mathbf{2 0 1 3}$ & $\mathbf{2 0 1 4}$ & $\mathbf{2 0 1 5}$ & $\mathbf{2 0 1 6}$ \\
\hline Kab. Gresik & 6,05 & 7,04 & 6,58 & 5,50 \\
Kab. Bangkalan & 0,19 & 7,19 & $-2,66$ & 0,66 \\
Kab. Mojokerto & 6,56 & 6,45 & 5,65 & 5,41 \\
Kota Mojokerto & 6,20 & 5,83 & 5,74 & 5,77 \\
Kota Surabaya & 7,58 & 6,96 & 5,97 & 6,00 \\
\hline
\end{tabular}




\begin{tabular}{lllll}
\hline Kab. Sidoarjo & 6,89 & 6,44 & 5,24 & 5,51 \\
Kab. Lamongan & 6,93 & 6,30 & 5,77 & 5,86 \\
\hline
\end{tabular}

Sumber:BPS Jatim Dalam Angka, 2017.

Hasil penelitian dari Werimon (2005), menyatakan bahwa pengetahuan dewan tentang anggaran berpengaruh positif signifikan terhadap pengawasan keuangan daerah. Adanya partisipasi masyarakat tidak berpengaruh terhadap perilaku dewan dalam melaksanakan fungsi pengawasan. Interaksi antara pengetahuan dewan tentang anggaran dengan transparansi kebijakan publik berpengaruh negatif signifikan terhadap pengawasan APBD. Interaksi antara pengetahuan dewan tentang anggaran dengan partisipasi masyarakat dan transparansi kebijakan publik berpengaruh negatif signifikan terhadap pengawasan APBD. Penelitian tersebut menggunakan APBD sebagai salah satu variabel dependen, sedangkan penelitian ini menggunakan APBD sebagai variabel independen. Selain itu, Werimon juga mencantumkan tingkat partisipasi masyarakat serta transparansi kebijakan publik, yang sekaligus ia gunakan sebagai variabel independen. Sedangkan penelitian ini membatasi permasalahan hanya pada APBD dan kinerja pembangunan daerah serta pengaruhnya terhadap PDRB, yang mana PDRB ini digunakan sebagai variabel dependennya.

Hasil penelitian dari Kumorotomo (2010), konstelasi politik yang sudah lebih demokratis di Indonesia saat ini belum memungkinkan terciptanya akuntabilitas anggaran publik yang baik, disebabkan karena masih lemahnya substansi demokrasi dan kebijakan desentralisasi di Indonesia. Sistem administrasi publik yang berlaku juga belum mampu menciptakan sistem anggaran yang terbuka bagi publik serta memprioritaskan belanja publik dengan komitmen aparat yang memadai. Penelitian Kumorotomo (2010), lebih berfokus pada permasalahan mengenai Akuntabilitas anggaran publik yang dikaitkan dengan beberapa hal, salah satunya memuat tentang isu politik. Sedangkan penelitian ini hanya berfokus pada pembahasan mengenai APBD, yang dikaitkan dengan kinerja pembangunan daerah, serta dampaknya bagi pertumbuhan ekonomi.

Hasil penelitian Mayasari (2012), kualitas anggota dewan berpengaruh terhadap pengawasan APBD. Adanya akuntabilitas publik dapat meningkatkan pengawasan APBD oleh Anggota Dewan. Adanya partisipasi masyarakat dapat meningkatkan pengawasan APBD oleh anggota dewan. Transparansi kebijakan publik tidak berpengaruh terhadap hubungan antara kualitas Anggota Dewan dengan pengawasan APBD. Penelitian tersebut menggunakan variabel pengawasan APBD sebagai variabel dependen, sedangkan variabel dependen dalam penelitian ini menggunakan PDRB. Variabel independen yang digunakan oleh Mayasari, adalah kualitas anggota 
dewan, yang di dalamnya juga membahas mengenai tata pemerintahan yang baik sebagai variabel moderating, sedangkan penelitian ini membatasi permasalahan hanya pada struktur APBD yang dihubungkan dengan kinerja pembangunan daerah.

Dalam metadata yang menjelaskan mengenai PDRB, Bank Indonesia menyatakan bahwa PDRB Atas Dasar Harga Konstan (ADHK) menunjukkan nilai tambah barang dan jasa tersebut yang dihitung menggunakan harga yang berlaku pada satu tahun tertentu sebagai tahun dasar, dan digunakan untuk mengetahui pertumbuhan ekonomi secara riil dari tahun ke tahun atau pertumbuhan ekonomi yang tidak dipengaruhi oleh faktor harga. Untuk menghitung pertumbuhan ekonomi riil, terlebih dahulu harus dihilangkan pengaruh perubahan harga yang melekat pada angka-angka agregat ekonomi menurut harga berlaku (current price) sehingga terbentuk harga agregat ekonomi menurut harga konstan (constant price). (Dumairy, 1997 dalam Syaparuddin, 2015). Berdasarkan teori pertumbuhan yang dikemukakan oleh ekonom klasik hingga Solow-Swan, dapat disimpulkan bahwa faktor-faktor yang berpengaruh terhadap pertumbuhan ekonomi adalah keadaan tenaga kerja, adanya penambahan stok barang-barang modal (capital stock), keadaan SDA, dan juga tingkat teknologi yang digunakan.

Tujuan diadakannya APBD, yang merupakan Rencana Kerja Pemerintah Daerah (RKPD) dalam bentuk uang (Rp) dalam masa 1 (satu) tahun adalah untuk mengatur pembelanjaan daerah dan penerimaan yang direncanakan supaya dapat mencapai sasaran yang ditetapkan, yaitu menciptakan pertumbuhan ekonomi dan kemakmuran masyarakat. (M. Idrak dkk, dalam Ekonomi Hafalan luar kepala, 2012). Dalam teori Keynes, menyatakan bahwa APBD merupakan salah satu mesin pendorong pertumbuhan ekonomi. Kebijakan pengelolaan APBD difokuskan pada optimalisasi fungsi dan manfaat pendapatan dan belanja daerah bagi tercapainya sasaran atas agenda-agenda pembangunan tahunan. (Anggreni, 2013). Pada penelitian Setiyawati dan Hamzah (2007), serta Syaparuddin (2015), menyatakan adanya pengaruh signifikan pada pendapatan khususnya Pendapatan Asli Daerah (PAD) terhadap pertumbuhan ekonomi. PDRB sebagai tolak ukur pertumbuhan suatu ekonomi regional tidak bisa lepas dari peran pengeluaran pemerintah di sektor layanan publik. (Rustiono, 2008). Pengeluaran pemerintah diukur dari total belanja rutin dan belanja pembangunan yang dialokasikan dalam anggaran daerah. Penelitian terdahulu yang menyatakan pengaruh signifikan belanja pembangunan/modal terhadap pertumbuhan ekonomi antara lain adalah penelitian Oktari (2017), Setiyawati dan Hamzah (2007), Syaparuddin (2015), serta Haque dan Denise (2007).

Syaparuddin (2015), menyatakan bahwa perlu adanya pengaturan mengenai hubungan pusat dengan daerah, sehingga kebutuhan pengeluaran yang menjadi tanggungjawab daerah dapat dibiayai dari sumber-sumber penerimaan yang ada oleh daerah. Prosesnya dapat melalui mekanisme dana perimbangan, yaitu pembagian penerimaan antar tingkatan pemerintahan guna menjalankan fungsi-fungsi pemerintahan dalam kerangka desentralisasi. Hal tersebut mengindikasikan dana perimbangan berpengaruh signifikan terhadap pertumbuhan ekonomi. Hasil penelitian Setiyawati dan Hamzah 
(2007), serta Bisma dan Susanto (2010) juga menyatakan pengaruh signifikan dana perimbangan terhadap pertumbuhan ekonomi. Dalam penelitian Kusuma (2016), disebutkan bahwa peran pemerintah pusat dalam membantu perekonomian di daerah tercermin dari berbagai macam dana transfer yang diberikan, seperti DAU, DAK dan DBH (dana perimbangan).

Secara umum, pembangunan ekonomi dapat dicapai dengan meningkatkan kesejahteraan masyarakat. Indikator kesejahteraan menurut BPS mencakup aspek kependudukan, kesehatan dan gizi, pendidikan, ketenagakerjaan, taraf dan pola konsumsi, perumahan dan lingkungan, kemiskinan, serta sosial lainnya yang menjadi acuan dalam upaya peningkatan kualitas hidup. Disimpulkan bahwa tingkat kesejahteraan dapat diukur melalui Indeks Pembangunan Manusia (IPM), dan jumlah angkatan kerjanya. Semakin tinggi IPM-nya maka akan semakin mudah untuk memenuhi kebutuhan-kebutuhan tersebut guna meningkatkan kualitas hidup. Semakin tinggi jumlah tenaga kerjanya maka semakin sedikit pengangguran dan akan berlanjut pada penekanan tingkat kemiskinan. IPM dihitung dengan mencakup tiga komponen, yaitu: umur panjang dan hidup sehat (A long and healthy life), pengetahuan (knowledge), dan standar hidup layak (A decent standart of living). (Badan Pusat Statistik Kabupaten Gresik, 2018).

Sasana, 2009 menyatakan pengaruh positif pertumbuhan ekonomi terhadap kesejahteraan masyarakat, yang dalam penelitian ini diukur dengan IPM dan AK, sehingga berkemungkinan adanya korelasi AK dengan pertumbuhan ekonomi. Primadona, dalam artikelnya manyatakan bahwa keberhasilan pembangunan ekonomi juga didukung oleh pembangunan manusia yang dikenal dengan IPM, ia juga menyatakan adanya pengaruh positif antara pertambuhan penduduk dengan perubahan tenaga kerja terhadap pertumbuhan ekonomi. Hasil penelitian Rustiono, 2008 menyatakan pengaruh positif Angkatan Kerja (AK) terhadap pertumbuhan ekonomi. Menurut Nurrohman dan Arifin (2010), keberhasilan pertumbuhan ekonomi adalah merata disetiap kabupaten/kota yang diikuti pula oleh penyerapan tenaga kerja.

Tercapainya otonomi daerah yang nyata, dinamis, dan bertanggungjawab adalah melalui pengoptimalan bantuan yang diberikan untuk dapat mengurangi kesenjangan antar daerah serta mengurangi ketergantungan dengan pusat. (Sudarti, 1998). Penerapan kebijakan otonomi daerah tidak serta merta menjadikan daerah mandiri dan mampu membiayai segala aktifitas pembangunan daerah melalui optimalisasi perolehan sumbersumber pendapatan daerah untuk membiayai belanja daerah. Kemandirian daerah juga sangat bergantung dari besarnya potensi sumber-sumber pendapatan daerah untuk membiayai belanja daerah. Aspek penting lainnya yang juga tidak dapat dikesampingkan adalah adanya dukungan kualitas Sumber Daya Manusia (SDM) yang memadai sebagai penggerak roda pembangunan. (Bisma dan Susanto, 2010).

Tujuan dari penelitian ini adalah untuk mengetahui pengaruh dari APBD khususnya dari sisi pendapatan/penerimaan daerah, meliputi Pendapatan Asli Daerah (PAD) dan dana perimbangan, serta dari sisi belanja daerah terutama belanja pembangunan/modal, juga mengetahui pengaruh dari kinerja pembangunan daerah yang diukur melalui Indeks Pembangunan 
Manusia (IPM), dan jumlah Angkatan Kerja (AK) terhadap pertumbuhan ekonomi di Gerbangkertasusila tahun 2008-2017.

\section{METODE PENELITIAN}

Penelitian ini menggunakan data panel dengan sumber data sekunder. Lingkup penelitian adalah studi empiris pada instansi pemerintah tingkat Kota dan Kabupaten di Provinsi Jawa Timur. Data yang digunakan antara lain adalah data-data publikasi yang diperoleh dari situs Dinas dan Instansi terkait, yaitu Badan Pusat Statistik Propinsi Jawa Timur dan Kabupaten/Kota Gerbangkertasusila, Direktorat Jenderal Perimbangan Keuangan, serta berbagai buku referensi dan kepustakaan yang dianggap relevan dengan maksud dan tujuan penelitian

Variabel bebas yang digunakan dari struktur APBD meliputi Pendapatan Asli Daerah (PAD) sebagai variabel bebas yang pertama (X1), dana perimbangan (X2), dan belanja pembangunan (X3), masing-masing dinyatakan dengan satuan rupiah (Rp). Kemudian, variabel dari indikator kinerja pembangunan daerah meliputi Indeks Pembangunan Manusia (IPM) sebagai variabel bebas yang keempat (X4), dinyatakan dalam presentase atau persen (\%), dan Angkatan Kerja (AK) (X5), yang dinyatakan dalam ribu dengan satuan jiwa. Sebagai variabel respon (dependent variable) adalah pertumbuhan ekonomi, yang diukur dari tingkat Produk Domestik Regional Bruto (PDRB) Atas Dasar Harga Konstan (ADHK) dengan satuan rupiah (Rp). Tahun penelitian masing-masing variabel menggunakan tahun 20082017.

Analisis data menggunakan metode Regresi Data Panel dengan tiga jenis estimasi parameter model, meliputi Common Effect (CE), Fixed Effect (FE) dan Random Effect (RE). Persamaan yang digunakan untuk tiga model estimasi tersebut adalah sebagai berikut:

$$
\log Y_{i t}=\beta_{0}+\beta_{1} \log P A D+\beta_{2} \log \text { Daper }+\beta_{3} \log I P M+\beta_{4} \log L+\beta_{5} \log G+e
$$

Dalam model tersebut, $i$ menjelaskan banyaknya unit cross-section yang digunakan dalam penelitian, sedangkan $t$ menjelaskan banyaknya data time series. Logaritma dari pertumbuhan ekonomi dituliskan dalam logYit, pendapatan asli daerah dituliskan dalam $\log P A D$, dana perimbangan dituliskan dalam logDaper, belanja pembangunan pemerintah dituliskan dalam $\log G$ (Government Expenditure), indeks pembangunan manusia dituliskan dalam $\log I P M$ dan logaritma jumlah angkatan kerja dituliskan dalam $\log L$ (Labour). $\beta_{0}$ adalah intersep dari pertumbuhan ekonomi, sedangkan $\beta_{1,} \beta_{2,} \beta_{3,} \beta_{4,} \beta_{5}$ adalah koefisien variabel, dan $e$ adalah error term.

Selanjutnya, digunakan uji chow untuk membandingkan model Fixed Effect dengan Common Effect, uji hausman untuk membandingkan model Fixed Effect dengan Random Effect, dan uji LM-Breusch pagan untuk membandingkan model Common Effect dengan Fixed Effect. Guna mengetahui bahwa model yang terpilih layak/valid, maka perlu dilakukan uji validitas kelayakan model, yakni melalui uji simultan (Uji F), uji parsial (uji t), dan uji koefisien determinasi $\left(\mathrm{R}^{2}\right)$. 


\section{HASIL DAN PEMBAHASAN}

Berdasarkan analisis menggunakan regresi data panel, diperoleh hasil bahwa model estimasi dengan metode Fixed Effect (FE) adalah yang paling sesuai untuk digunakan dalam penelitian ini. Model yang dihasilkan dari estimasi FE tersebut yaitu sebagai berikut:

$$
\begin{aligned}
\log P D R B= & 65,094087+0,858736 \log P A D+0,009413 \log \text { Daper }-0,037588 \\
& \log \text { Belanja-14,973160 } \log I P M+0,607515 \log A K
\end{aligned}
$$

Hasil yang diperoleh dari estimasi model Fixed Effect, dijelaskan secara lebih terperinci dalam tabel di bawah ini.

Tabel 2. Output Estimasi FE

\begin{tabular}{lcllc}
\hline Variabel & Koefisien & Prob. & Keterangan & Pengaruh \\
\hline C & 65,09409 & 0.0000 & Signifikan & + \\
PAD & 0,858736 & 0.0000 & Signifikan & + \\
Daper & 0,009413 & 0.9717 & $\begin{array}{l}\text { Tidak } \\
\text { Signifikan }\end{array}$ & + \\
& & & $\begin{array}{l}\text { Tidak } \\
\text { Signifikan }\end{array}$ & - \\
Belanja & $-0,037588$ & 0.6333 & Signifikan & - \\
IPM & $-14,97316$ & 0.0000 & Tidak & + \\
AK & 0,607515 & 0.5074 & Signifikan & \\
& & & & \\
Adj R2=0,975656 & Prob.F $=0,000$ & & \\
\hline
\end{tabular}

Sumber: Hasil Olah Data, 2019.

Variabel PAD diketahui berpengaruh positif dan signifikan terhadap pertumbuhan ekonomi, dengan nilai probabilitas 0,0000 kurang dari 0,05. Hasil ini selaras dengan penelitian dari Setiyawati dan Hamzah (2007), menyatakan adanya pengaruh positif PAD terhadap pertumbuhan ekonomi. Hasil penelitian Kusumawati dan Wiksuana (2018), juga menyatakan pengaruh positif PAD terhadap pertumbuhan ekonomi. Hal ini berarti setiap kenaikan pada PAD mencerminkan bahwa tingkat kesejahteraan daerah juga membaik, sehingga terjadi pertumbuhan ekonomi.

Variabel dana perimbangan diketahui tidak berpengaruh terhadap pertumbuhan ekonomi, dengan nilai probabilitas 0,9717 kurang dari 0,05. Hasil penelitian dari (Manek dan Badrudin, 2016). Dalam penelitiannya menyatakan faktor tersebut bisa disebabkan oleh belum maksimal serta idealnya pengalokasian dan pengelolaan dana perimbangan pada pembangunan infrastruktur yang bertujuan mendorong pertumbuhan ekonomi. Pengaruh negatif dari masing-masing variabel dana alokasi juga bisa menyebabkan tidak signifikannya variabel dana perimbangan terhadap pertumbuhan ekonomi.

Variabel belanja pembangunan diketahui tidak berpengaruh terhadap pertumbuhan ekonomi, dengan nilai probabilitas 0,6333 kurang dari 0,05. hasil penelitian yang menunjukkan hubungan negatif dan tidak signifikan pada variabel belanja pembangunan/modal, selaras dengan hasil penelitian dari Dewi dan Suputra, (2017), Irvan dan Karmini, (2016), dan Mawarni dkk, (2013), yang menyatakan pengaruh negatif belanja modal terhadap 
pertumbuhan ekonomi. Faktor penyebabnya bisa karena belanja modal yang tidak didasarkan pada kebutuhan sarana dan prasarana publik yang dapat meningkatkan produktifitas

Variabel IPM diketahui berpengaruh negatif signifikan terhadap pertumbuhan ekonomi, dengan nilai probabilitas 0,000 kurang dari 0,05. Mendukung penelitian dari Muqorrobin dan Soejoto (2017), yang dalam hasil penelitiannya mengemukakan bahwa IPM berpengaruh negatif dan signifikan terhadap pertumbuhan ekonomi. Hal ini bisa dikarenakan tidak meratanya pembangunan pada tiga komponen utama indeks pembangunan manusia (IPM), yakni indeks kesehatan, pendidikan, dan indeks daya beli.

Variabel angkatan kerja diketahui tidak berpengaruh terhadap pertumbuhan ekonomi, dengan nilai probabilitas 0,5074 kurang dari 0,05. Hal ini mendukung hasil penelitian yang dikemukakan Rusalia (2018), Latif dan Soesatyo (2015), dan Bawuno dkk, (2015), yang menyatakan pengaruh negatif perubahan angkatan kerja terhadap pertumbuhan ekonomi. Penyebabnya antara lain karena Sumber Daya Manusia yang merupakan faktor penting dalam produksi belum dapat dimanfaatkan dengan efektif, terlebih penduduk asli daerah dan juga angkatan kerja berkualitas yang belum terserap dengan baik akibat kesediaan lapangan kerja yang kurang memadai.

Melalui hasil pengujian secara statistik, diperoleh nilai probabilitas $\mathrm{F}$ lebih kecil dari 0,05 (Prob.F-statistics $<\alpha$ ), yaitu sama dengan 0,000, maka diputuskan untuk tolak H0. Sehingga, disimpulkan bahwa seluruh variabel independen dalam penelitian secara bersama-sama/simultan berpengaruh terhadap variabel respon yaitu pertumbuhan ekonomi. Sedangkan hasil analisis pengujian parsial, diperoleh output nilai probabilitas $F$ untuk variabel PAD dan IPM adalah lebih kecil dari 0,05 (Prob.F-statistics $<\alpha$ ), dan output nilai probabilitas $\mathrm{F}$ lebih besar dari 0,05 (Prob.F-statistics $>\alpha$ ) untuk variabel dana perimbangan, belanja pembangunan dan AK. Sehingga variabel yang berpengaruh positif dan signifikan terhadap pertumbuhan ekonomi di Gerbangkertasusila tahun 2008-2017 secara parsial adalah PAD. Koefisien determinasi sebesar 0,975656 atau $97,56 \%$ hal ini memperlihatkan bahwa kemampuan variabel bebas terhadap variabel terikat adalah sebesar 97,56\%, sedangkan sisanya 2,05\% dijelaskan oleh variabel lain diluar model.

\section{KESIMPULAN}

Model Regresi Data Panel dengan metode estimasi Fixed Effect (FE) sesuai untuk digunakan dalam pemodelan pertumbuhan ekonomi (PDRB) di wilayah Gerbangkertasusila tahun 2008-2017. Diketahui dari besarnya nilai koefisien determinasi yaitu 0,9795337 atau 97,56\%. Melalui model tersebut diketahui seluruh variabel independen dalam penelitian secara bersamasama/simultan mempengaruhi pertumbuhan ekonomi secara positif dan signifikan. Namun, yang secara parsial berpengaruh positif dan signifikan terhadap pertumbuhan ekonomi di Gerbangkertasusila (Y) selama kurun waktu 10 (sepuluh) tahun tersebut hanya Pendapatan Asli Daerah (PAD), dengan nilai probabilitas lebih kecil dari 0,05 (p-value $<\alpha$ ). Sedangkan pada variabel IPM menunjukkan hubungan yang negatif signifikan dengan 
pertumbuhan ekonomi. Pada variabel dana perimbangan, belanja pembangunan dan AK menunjukkan hubungan yang negatif serta tidak signifikan terhadap pertumbuhan ekonomi di wilayah Gerbangkertasusila pada tahun 2008-2017.

\section{DAFTAR PUSTAKA}

Anggreni, D. 2013. "Deskripsi Kebijakan Fiskal Daerah Terhadap Kemiskinan di Provinsi Lampung". Skripsi Program Studi Ekonomi Pembangunan Fakultas Ekonomi dan Bisnis Universitas Lampung.

Bisma, I D. G., \& H. Susanto. 2010. "Evaluasi Kinerja Keuangan Daerah Pemerintah Provinsi Nusa Tenggara Barat Tahun Anggaran 20032007”. GaneÇ Swara Edisi Khusus, Volume 4 No.3.

Djpk. 2018. "Website resmi Direktorat Jenderal Perimbangan Keuangan". www.djpk.kemenkeu.go.id/ [diakses pada 2 November 2018]. Media.

Idrak, M., dkk. 2012. Ekonomi: Hafalan luar kepala. Yogyakarta: Becla

Kumorotomo, W. 2010. "Akuntabilitas Anggaran Publik: Isu Politik, Prioritas Belanja dan SiLPA Dalam Alokasi APBD di Beberapa Daerah". Makalah dipaparkan pada Konferensi Administrasi Negara ke-3, Bandung, 68 Juli 2010.

Kusuma, H. 2016. "Desentralisasi Fiskal dan Pertumbuhan Ekonomi di Indonesia". Jurnal Ekonomi Kuantitatif Terapan, Vol. 9 No. 1.

Kusumawati, L., \& I.G.B. Wiksuana. 2018. "Pengaruh Pendapatan Daerah Terhadap Pertumbuhan Ekonomi Di Wilayah Sarbagita Provinsi Bali". E-Jurnal Manajemen Unud, Volume 7, N0. 5.

Nuraini, I. 2010. "Analisis Sumber-Sumber Pertumbuhan Output Regional Kota Malang". Humanity, Volume 5 Nomor 2, Maret 2010: 109115.

Nuraini, I. 2017. "Kualitas Pertumbuhan Ekonomi Daerah Kabupaten/Kota Di Jawa Timur". Artikel dipresentasikan pada Seminar Nasional \& Call For Paper, FEB Unikama: Peningkatan Ketahanan Ekonomi Nasional Dalam Rangka Menghadapi Persaingan Global, Malang, 17 Mei.

Nurrohman, R., \& Z. Arifin. 2010. "Analisis Pertumbuhan Ekonomi Dan Penyerapan Tenaga Kerja di Provinsi Jawa Tengah". Jurnal Ekonomi Pembangunan, Vol 8 No. 1.

Oktari, A. 2017. "Pengaruh Tingkat Investasi dan Belanja Pemerintah Terhadap Produk Domestik Regional Bruto di Provinsi Lampung Dalam Perspektif Ekonomi Islam". Skripsi Program Studi Ekonomi Islam Fakultas Ekonomi dan Bisnis Islam Institut Agama Islam Negeri Raden Intan Lampung.

Pasomba, Y. 2015. "Analisis Pengaruh Perkembangan Penduduk dan PDRB Terhadap Tingkat Konsumsi Masyarakat di Melongguane Kabupaten Talaud". Penelitian FEB Program Magister Ilmu Ekonomi Universitas Sam Ratulangi Manado. 
Primadona. "Pengaruh Pertumbuhan Penduduk Terhadap PDRB dan Angkatan Kerja di Kota Payakumbuh". Artikel penelitian Dosen Politeknik Negeri Padang Jurusan Administrasi Niaga.

Rahardja, P., \& M. Manurung. 2008. Pengantar Ilmu Ekonomi: Edisi ketiga. Jakarta: Lembaga Penerbit Fakultas Ekonomi Universitas Indonesia.

Rustiono, D. 2008. "Analisis Pengaruh Investasi, Tenaga Kerja, dan Pengeluaran Pemerintah Terhadap Pertumbuhan Ekonomi di Propinsi Jawa Tengah". Tesis Program Magister Ilmu Ekonomi \& Studi Pembangunan Universitas Diponegoro Semarang.

Sasana, H. 2009. "Peran Desentralisasi Fiskal Terhadap Kinerja Ekonomi di Kabupaten/Kota Provinsi Jawa Tengah". Jurnal Ekonomi Pembangunan, Volume 10, N0.1 (hlm. 103-124).

Setiyawati, A., \& A. Hamzah. 2007. "Analisis Pengaruh PAD, DAU, DAK, dan Belanja Pembangunan Terhadap Pertumbuhan Ekonomi, Kemiskinan, dan Pengangguran: Pendekatan Analisis Jalur". Jurnal Akuntansi dan Keuangan Indonesia, Volume 14 (hlm. 211-228).

Sudarti. 1998. "Otonomi Daerah dan Pola Hubungan Keuangan PusatDaerah". Bestari, September-Desember.

Werimon, S. 2005. "Pengaruh Partisipasi Masyarakat dan Transparansi Kebijakan Publik Terhadap Hubungan Antara Pengetahuan Dewan Tentang Anggaran Dengan Pengawasan Keuangan Daerah (APBD): Studi Empiris di Provinsi Papua". Tesis Program Magister Sains Akuntansi Universitas Diponegoro Semarang.

Wikipedia. 2019. https://id.wikipedia.org/ [diakses pada 7 April 2019]. 